\title{
高周波微小容量測定装置を検出部とする スライバ太さ自動制御の基礎的な研究"
}

（第 1 報） 制御装置の構成と検出部特性

$\begin{array}{llllll}\text { (昭和39年 } 5 \text { 月19日受理) 会 } & \text { 員 } & \text { 井 } & \text { 原 } & \text { 素 } & \text { 三粘 } \\ & \text { " } & \text { 高 } & \text { 木 } & \text { 節 } & \text { 雄 } \\ & \text { " } & \text { 佐 } & \text { 藤 } & \text { 文 } & \text { 二 }\end{array}$

\footnotetext{
$\sqrt{20}$

目

的

要

本研究に使用した制御装置構成の概要を説明し，さらに検出部特性に影響を与える要因を明らかにする.

成

果

（1）本制御装置は高周波微小容量測定装置を検出部, 電気一油圧パワーアクタと P.I.V.無段变速機を組み 合わせたるのを操作部とし，さらに調節計拈よび二，三の補助装置を含めて構成されている.

（2）検出部特性変動の原因は，同調点偏差に関係のあるものと関係のないものとにわけることがでさる.

（3）同調点偏差を生ずる原因としては, 計器のスイッチを入れてからの真空管などの特性の変化, 周囲の温湿 度の変化が考えられる.
}

（4）同調点偏差に関係がなくて検出部の特性を決定するものとしては計器の増幅度, 測定電極の構造, 瀻維物 質の誘電率および水分率などである゙.

（5）検出部の時定数は Normal の場合でほぼ $0.2 \mathrm{sec}$, Inert の場合で $1.6 \mathrm{sec}$ である.

\section{1.は じめに}

スライバ中の繊維の平行度をたかめ, 太さむらを減少 させるためにダブリングとドラフトをくり返ずという方 法に対して，繊維の配列は一応別として，スライバの太 さむらの減少方法として紡出の際にドラフトを調節して 紡出スライバの太さを均一にしてダブリングの本数を減 少させようとする試みは，すでに 1884, 年アメリカ人 A. T. Atherton によって特許がとられているが，1953年 プリンス・スミス社のオートレベラが発表されて以来, このような方式は折りから第二次大戦後急速に発展して さた自動制御工学の発展とともにめざましい発展をつづ け，わが国に和いてもすでに多くのスライバ太さ自動調 節装置が実用化されている。いをそれらの装置および今
後実用化されると思われる装置を表にまとめると第 1 表 のようになる。この表から明らかなようにスライバ太さ の自動調節装置の大部分は機械的な検出方式であり, ス ライバの太さむらの測定器としては王座を獲得した観の ある繊維物質の誘電率を利用した検出方法は, ただ $\mathrm{A}$. D.C. (Automatic Draft Control) で利用されているに すぎない。このように物質の誘電率を利用した高周波微 小容量測定装置が，自動調節の検出部としてあまり利用 されていないのはこの装置が温度や湿度の影響を受け やすいこと, ドリフトが生じやすいこと和よび経済的に 高価で取り扱いが面倒であるなどの理由によるものと思 われる、おれわれは本研究に利いて一応経済的な理由は 別として, このような電気容量型の検出部を自動制御に 用いた場合の基礎的な問題点を検討する.

* Study on Automatic Control of Sliver Thickness by High-Frequency Small Capacitance Mesuring Principle. Part 1: Constitution of the Automatic Controller and Properties of the Detecting Means.

** M. Ihara, S. Takagi and B. Sato, members. 静岡大学工学部 
（第 1 表）絨維束の太さ自動調節装置の分類

\begin{tabular}{|c|c|c|c|c|c|c|c|}
\hline & \multicolumn{3}{|l|}{ 国 } & \multicolumn{3}{|l|}{ 国 } \\
\hline & & 称 & 検 出端 & 製 作 者 & 称 & 検 出 端 & 製 作 者 \\
\hline \multirow{2}{*}{ 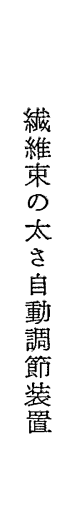 } & $\begin{array}{l}\text { 開 } \\
\cdots \\
1 \\
2^{\circ} \\
\text { 方 } \\
\text { 式 }\end{array}$ & $\begin{array}{l}\text { スーパレベラ } \\
\text { サーボ ドラフト機 } \\
\text { オートレベライザ } \\
\text { オートイブナ } \\
\text { A.E.D.制御装置 } \\
\text { サンプロング制御 } \\
\text { フリクタ }\end{array}$ & 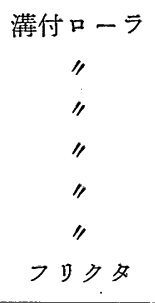 & $\begin{array}{l}\text { 神戸工業 } \\
\text { 東 洋 紡 } \\
\text { 大阪機工 } \\
\text { オー×ム } \\
\text { 日 東 絃 } \\
\text { 松 本 }\end{array}$ & $\begin{array}{l}\text { オート レべラ } \\
\text { レーゲルストレッケ } \\
\text { A.D.C. }\end{array}$ & 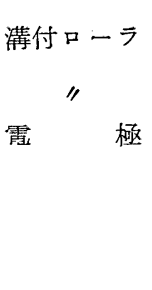 & $\begin{array}{r}P^{\circ} \text { リス } \\
\text { スミス } \\
\text { ベルンハルト } \\
\text { サコロウェル }\end{array}$ \\
\hline & $\begin{array}{l}\text { 閉 } \\
ル \\
1 \\
フ^{\circ} \\
\text { 方 } \\
\text { 式 }\end{array}$ & $\begin{array}{l}\text { オート ドラフタ } \\
\text { エバイブン } \\
\text { ドラフトカ制御機 }\end{array}$ & 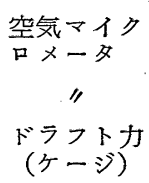 & $\begin{array}{l}\text { 豊田織機 } \\
\text { 大 和 紡 } \\
\text { 石川・清水 } \\
\text { 井原 ・高木 }\end{array}$ & ドラフトカ制御装置 & $\begin{array}{c}\text { ドラフトカ } \\
(\text { ゲージ) }\end{array}$ & ウェグネル \\
\hline
\end{tabular}

（注）名称恬必ずしも正式の名称ではない

2. 制御装置の各ブロックの選定とブロック 線図

一般に制御装置のブロック線図は第 1 図のよらなブロ ックからなりたっているが，これらのブロックを構成す る装置は，この制御機構に要求される制御の性格に適ず るように選定されなければならないが，スライバ太さの

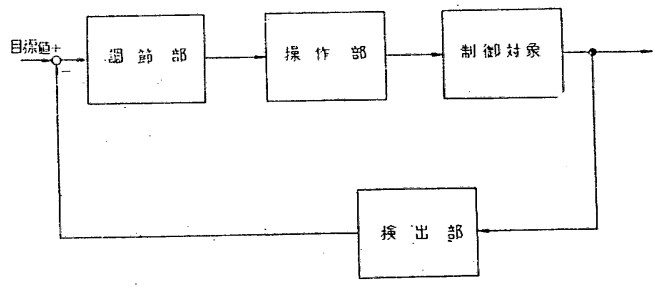

（第1図）、制御系のブロック線図

制御装置では基礎的な問題が必ずしも明らかにされてい るとはいえないので，あらかじめ最適の装置を選定する のは困難である。したがって基礎的な問題を明らかにす る装置として，比較的可変範囲の広い装置を選定した，

\section{1 制御対象}

制御対象としての紡機は，オートレベラ付インタセ クチング ギル ボックス（オート レベライザ）でその ギヤ ダイアグラムは第 2 図のと拉りである.この紡機に は別の報交で報告したように，開ループ方式のスライバ 太さ自動修正装置が付属しているが；本研究では修正装 置は作動させずギル ボックスの部分だけを用いた。

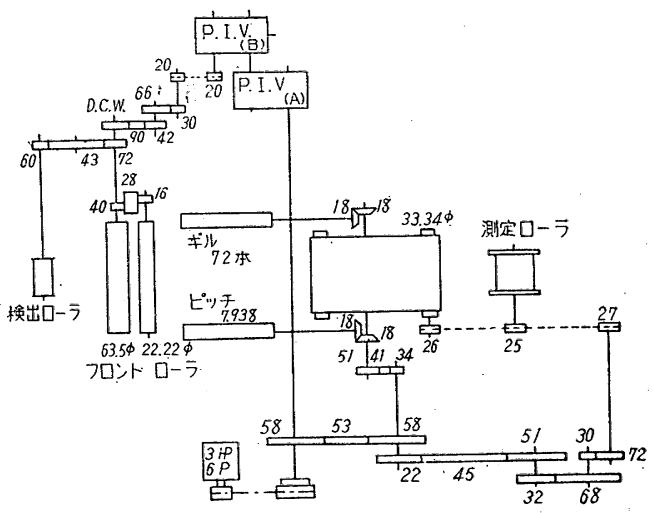

（第2 図） 制御対象としての䋡機のギヤ ダイアグラム

\section{2 検 出 部}

検出部は第 3 図のように電極, アダプタおよびイブネ

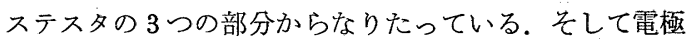
は第4図のような外観をしていて，その構造および容量 は第 5 図和よび第 2 表のとおりである。ここで電極がA と Bの 2 種類あるのは電極の容量および構造が検出部の 特性にあたえる影響を明らかにするために製作したるの

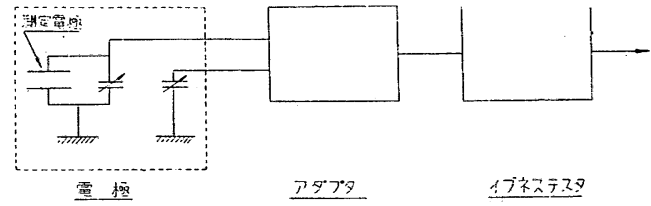

（第 3 図）震極の構造の原理図 


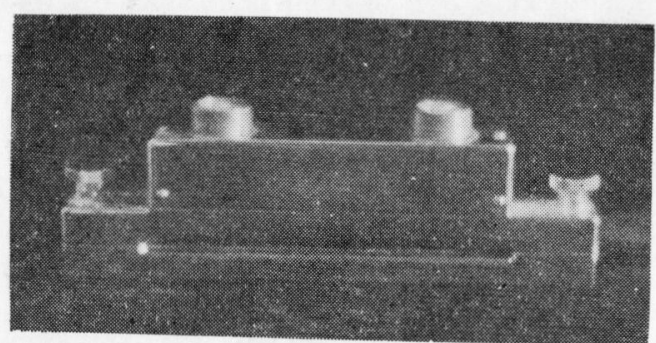

（第４，図）測定電極外観図

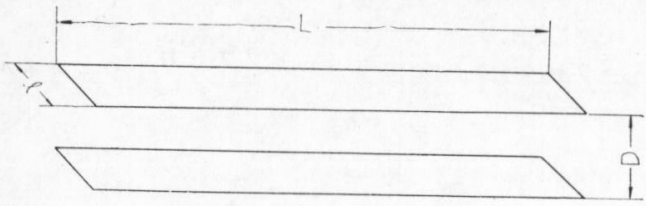

（第 5 図）電 極 の 構 造

(第 2 表)

\begin{tabular}{|c|c|c|c|c|}
\hline $\begin{array}{l}\text { 震 極 } \\
\text { 種 } \\
\text { 類 }\end{array}$ & $\begin{array}{c}L \\
(\mathrm{~mm})\end{array}$ & $\begin{array}{c}l \\
(\mathrm{~mm})\end{array}$ & $\begin{array}{c}D \\
(\mathrm{~mm})\end{array}$ & 容 量 \\
\hline A & 150 & 10 & 5.0 & $2.66^{\text {P.F }}$ \\
\hline B & 100 & 10 & 3.5 & 2.52 \\
\hline
\end{tabular}

である、またアダプタはウスタ ラップバリメータのア ダプタを上記の電極に合うように若干の改造を行なっ た.イブネステスタはウスタイブネステスタをその まま用いた。なお電極は計測器工業製である。

\section{3 調 節 部}

検出部の出力は電圧であるから，この研究に用いる調 節計は電気式とし，実験用のために P.I.D.調節計を 太陽社に試作してもらった。この調節計の仕様はつぎの とおりである。

$$
\begin{aligned}
& \mathrm{P}: 5 \sim 300 \% \text { 連 続 可鸾 } \\
& \mathrm{I}: 0.1 \sim 10 \mathrm{sec} \\
& \mathrm{D}: 0 \sim 5 \mathrm{sec}
\end{aligned}
$$

\section{4 操 作 部}

操作部はフロントローラの表面速度を変化させる部 分であるが, この研究では操作部の变速装置として P. I．V. 無段変速機を用いた．P．Ｉ．V.無段变速機は相 当大きな時定数をもっているから，この研究に打ける操 作部の変速装置として, 適当かと゚らかという疑問もある が，その問題は後で検討する。ここで使用した無段変速 機はチェーンギャ無段変速機製NR-2 型 $(2 \mathrm{P})$ であ る.なお第 2 図から明らかなように, この紡機には開ル ープ方式によるスライバ太さ自動修正用の P.I.V. 無
段変速機（ドイッ製）がついているか゚，開ループ，閉ル 一プ両方式を同時に使用できるよらに，第2図のように P. I . V.を2 個直列に結合した。

つぎに前にも述ぺたように，調節計の出力（直流電流 $5 \sim 25 \mathrm{~mA}$ ) と無段変速機の变速軸（回転角度）を結び つける装置としては, 電気一油压式のアクチェータを用 いた.このアクチェータは横河電機製 E H-21 電気一油 圧式パワーアクタで，その動作原理は第6図のとおりで ある.すなわち調節計からの電気信号は直流 $5 \sim 25 \mathrm{~mA}$

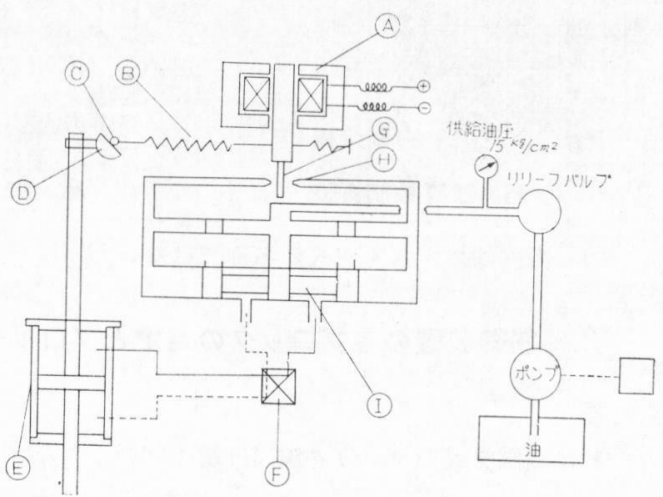

（第6図）電気一油圧パワーアクタの原理図

でトルクモータ (A) 内部のコイルに入りトルクを発生さ せ平衡時にはフィードバックスプリング (B)と作用し合 っている. 可動鉄片の先端はフラッパ (G) たなていて, 両側のノズル (H) にはさまれている。このノズルには油 圧ポンプから $15 \mathrm{~kg} / \mathrm{cm}$ の油压が固定絞りを通って供給 されている. いまフラッパ (G)が両側のノズルの中央に あれぱ，ノズル背圧は両側とも同じであるが，フラッパ が右側にかたよれぱ右側の背圧が高くなり左側の背圧か゚ 低くなる，この両背圧はスプール (I) の両端にかかるか゚， 背圧が等しいときにはスプールは両端のスプリングの力 によって中央の位置にあり，ピストンにかかる压力は上 下等しくなっている. フラッパ (G)がわずかに右によれ ばノズルの背圧に差を生じ，スプール (I)はその両端の 差圧によって左に動き，パワーシリンダ $\mathrm{E}$ は下方に動 く、パワーシリンダ (E) の動きはカムを介してフィード パックスプリング (B) に伝わり，フラッパ (G)が右によ ったのを中央に引きもどす力が働らく。このようにして トルクモータ (A)のトルクとパワーシリンダ (ㅅ) の位置 によるフィードパックスプリングのカがバランスした 位置でパルブ ステムは止り，したがって入力信号に対し て操作端の位置は比例した位置をとる。 


\section{5 その他の付属装置}

これからの装置のほかに検出部のドリフト補正や，繊 維の水分率による検出部の差異を補正する装置, 高域ろ 波器などの補助装置が必要であるが，それらの装置に ついては後でくわしく述べることにしてここでは省略 する.

以上が本研究に使用した装置の構成であるが，これら のブロック線図を再度書き表わすと第 7 図のようになる。

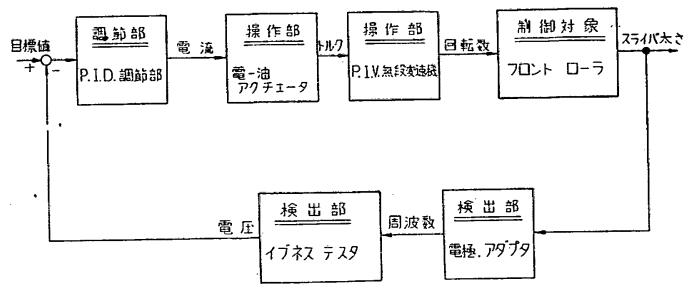

（第 7 図） 制御装置のプロック線図

\section{3. 検 出 部 特 性}

前述のような制御回路を構成する場合に，回路を構成 している各ブロックの特性を充分はあくしておく必要が あるので，まず最初に検出部としての高周波微小容量測 定装置の特性について検討する。

\section{1 検出部の構成}

検出部構成の概要については前述のとおりであるが, ここでさらに細かく述べる.検出部は電極,アダプタおよ びイブネステスタの 3 つ部分からなりたっていること は第 3 図に示したと和りであるが，これらの構成と動作 原理を図で表わすと第 8 図のようになる。すなわち $2 つ$
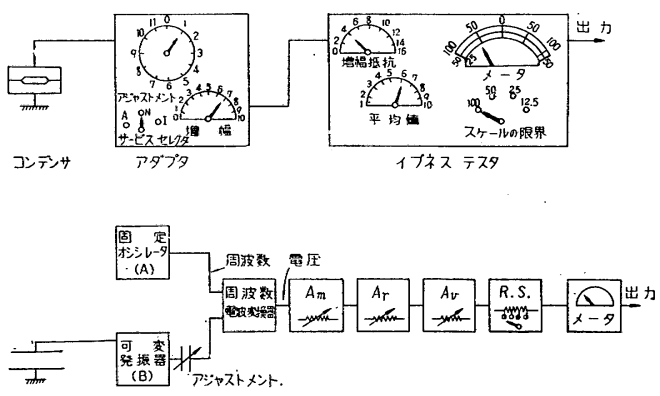

（第 8 図）检出部の構造と動作原理図

の高周波発振器 $\mathrm{A}, \mathrm{B}$ があり，一方は固定した周波数（約 3 メガサイクル) を発振しているが，もら一つの発振器 の発振回路中に測定電極拈よび調整用可变コンデンサが 組み入れられている. そしてこれら 2 つの発振器の発振
周波数は重站合わされ，“さらに電圧に変換される。そし

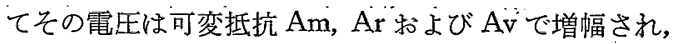
さらに Range of scale. で4 段切替増幅され, メータ を経てインテグレータもしくは記録計に連結される。

いま測定用電極に物質が入っていないとき，可変コン デンサ (Adjustment) で両方の発振器の周波数が重なり 合うように調節すると電圧は最低となりしたがってメ 一タの指示は負の最大をしめす。このように調整するこ とをこの報文では同調を取ると呼び，このような状態で のアジャストメントの指示点を同調点 (Adjustment point）と呼ぶことにする。この同調の状態で測定電極中 に物質がそう入されると測定電極の容量変化が生じ，そ の結果両方の発振器の周波数が重合しなくなってメータ に電流が流れるそそしてメータの電流は測定電極中の物 質の量に比例する。（以上の操作はラップバリメータの 操作と同じである)

アジャストメシト用の可変コンデンサは 3.6 5.7 P.F の容量変化が可能 : (26 $\frac{5}{12}$ 回転) であり, アシシャストメ ント用端子の 1 回転を 12 等分して図のように時計の針 と同方向に目盛が付してある。 また図中の Am はアダ プタに取りつけられた $5 \mathrm{k} \Omega$ の可変抵抗で，その可動角 度を 10 等分して 0 〜 10 の目盛がつけられている。同様 の可変抵抗 $\mathrm{Ar}$ はイブネステスタの裏面に取りつけられ ていて，その可動角度を16等分して $0 \sim 16$ の目盛が付し てある。また Av はイブネステスタの平均值で可動角を 9 等分して1〜10の目盛がついていて，R.S.はイブネ ステスタの Range of scale で 100，50，25\% 就よび 12.5\%の 4 段切替になっている. 最後のメ一タはイブネ ステスタのメータで $0 \sim 30 \mathrm{~mA}$ の直流電流計でメータ の中央に 0 点があり，メータの目盛はこの中央の值に対 する百分率で付されている。

\section{2 同調点の変動について}

前記のように測定電極中に物質がそら入されない状態 で，2つの発振器の発振周波数が重合されてメ一タの電 流が負の最大值（この操作は R.S.が $100 \%$ で行なう からメータの指示はー100\%）になるようにすることを 同調と呼び，このような状態になったときのアジャ゙スト メントの指示点を同調点と定義することは前に述べたが この同調点は機器にスイッチが入れられてから時間が経 過するにしたがって变動するし，また周囲の温湿度によ っても変動する。このような同調点変動の原因になると 思われるいくつかの項目について実験した結果第 3 表の ようになる，表中の○印は変動の原因となるものであり 
（第 3 表）

\begin{tabular}{c|lc|c}
\hline \hline 番 号 & \multicolumn{1}{|c|}{ 項 } & 目影 響 \\
\hline (1) & 電極の種類 \\
(2) & サービス セレクタ & $\bigcirc$ \\
(3) & 増 幅 & $\times$ \\
(4) & 増幅 抵 抗 & $\times$ \\
(5) & 平 均 值 & $\times$ \\
(6) & スケールの限界 & $\times$ \\
(7) & 周囲の温度 & $\times$ \\
(8) & 周囲の湿度 & $\bigcirc$ \\
(9) & 経過時間 (ドリフト) & $\bigcirc$ \\
\hline
\end{tabular}

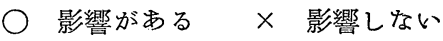

×印は変動の原因とならないものである，ここで電極の 種類（容量）が変われば同調点が変わるのは当然として 温度や湿度の変化によって同調点が変わるのは, 主とし て第 3 図に示した電極中に組み込まれている可変コンデ ンサの容量変化によるものと考觉られる．また経過時間 による同調点の変動は, 機器の温度上昇による特性の変 化（いわゆるドリフト）によるものと思われる。なおこ れらの変化の様子についてはあとでくわしく説明する.

\section{3 零点太さの変動について}

測定電極中に物質がそう入されていて,メータの指示 が 0 である場合の物質の乾燥時の太さ（単位長さ当りの 重量）を零点太さと定義すると，このような零点太さは あらかじめ乾燥時の重量のわかっているロービングを用 意し，これを 1 本ずつ電極中にそら入して行き，メータ が 0 を指すときのロービングの重量（乾燥時の）を求め ることによって得られる。このような方法で零点太さを 求め, 実験結果から零点太さに影響を与える因子を表に まとめると第 4 表のようになる，電極の種類（この場合 は容量よりももしろ構造によると思われる）によって零 点太さが変わるのは当然であるが，機器にとりつけられ た増幅端子のうち Am, Ar および Av もまた零点太さ に影響する。一方電極にそう入される物質の側からみれ ば，そら入される物質が異なれば，その物質の誘電率の 違いによって零点太さは異なるし，また同じ物質であっ ても゙，そう入されるときの水分率が異なると零点太さが 変わる。また温度や湿度のようなそう入時の周囲の状況 によっても零点太さは異なるが，この場合には温湿度の 変化によって物質の水分率が変わり, その結果として零 点太さが変わるのと, 温湿度の変化によって同調点に偏 差が生じ，その結果として零点太さが変わる場合との両 方がある。いずれにしてもこのような場合には間接的な
（第 4 表）

\begin{tabular}{|c|c|c|c|}
\hline & 項 & 目 & $\begin{array}{l}\text { 影響の } \\
\text { 有 無 }\end{array}$ \\
\hline $\begin{array}{l}\text { (1) } \\
\text { (2) } \\
\text { (3) } \\
\text { (4) } \\
\text { (5) } \\
\text { (6) }\end{array}$ & 機 器 & $\begin{array}{c}\text { 電 極 の種 類 } \\
\mathrm{S} . \mathrm{S} . \\
\mathrm{Am} \\
\mathrm{Ar} \\
\mathrm{Ar} \\
\mathrm{R} . \mathrm{S} .\end{array}$ & $\begin{array}{l}0 \\
\times \\
0 \\
0 \\
0 \\
\times\end{array}$ \\
\hline $\begin{array}{l}\text { (7) } \\
(8)\end{array}$ & そ5大物質 & $\begin{array}{l}\text { 物質 } \\
\text { 含 種 類 } \\
\text { 水 量 }\end{array}$ & $\begin{array}{l}0 \\
0\end{array}$ \\
\hline $\begin{array}{l}\text { (9) } \\
\text { (10) } \\
\text { (11) }\end{array}$ & 周囲の条件 & $\begin{array}{lll}\text { 温 } & & \text { 度 } \\
\text { 湿 } & & \text { 度 } \\
\text { 経 } & \text { 過 時 } & \text { 間 }\end{array}$ & $\begin{array}{l}\otimes \\
\otimes \\
\otimes\end{array}$ \\
\hline
\end{tabular}

$\bigcirc$ 影響する $\times$ 影響しない $\otimes$ 間接的に影響する

変化である. 経過時間（ドリフト）による零点太さの変 化もまた同調点偏差によって生ずるものであるから, (9) 〜11) の項はいずれも同調点偏差にまとめて考学ること ができる。これらの項目はその都度同調点偏差がなくな るように操作してから零点太さを求めれば取り除くこと ができる。

\section{4 検出部動特性の測定}

\section{(a) 測定の方法}

イブネステスタの出力をペン書きオッシログラフに連 結しておき，指示メ一タが 0 を指すようにする，そのよ らな状態から，イブネステスタの平均值を突変させ，そ のときの出力の応答から検出部の時定数を求める. この 結果は検出部全体の時定数ではなく，測定電極の影響は 含まれないが，検出部の時定数のおよその值をしめす。

\section{(b) 測定結果}

イブネステスタの平均值の值を突変させたときのイブ ネステスタの応答は第 9 図のようになる。ただしこの場 合の Range of scale は $100 \%$ ，ステップの大きさは

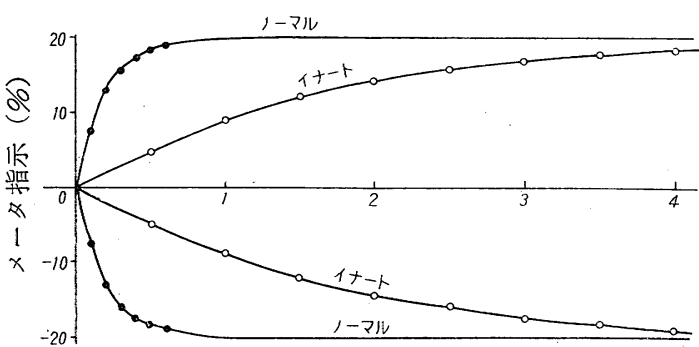

経過時間 $(\mathrm{sec})$

（第9図）イブネステスタの過渡応答 
$20 \%$ になるように調節した。 そして図の上部がプラス 側にステップした場合, 下部がマイナス側にステップし た場合である.この結果からイプネステスタの時定数を 求めると第 5 表のようになる，このとき定数は測定電極

（第 5 表）

\begin{tabular}{|c|c|c|c|}
\hline サービス セレクタ & $\begin{array}{r}\text { ステップ } \\
\text { の方向 }\end{array}$ & $\begin{array}{l}\text { 時 定 数 } \\
(\mathrm{sec})\end{array}$ & $\begin{array}{c}\text { 時定数(平均) } \\
\text { (sec) }\end{array}$ \\
\hline \multirow{2}{*}{ Normal } & + 側 & 0.198 & \multirow{2}{*}{0.201} \\
\hline & - 側 & 0.204 & \\
\hline \multirow{2}{*}{ Inert } & $+\quad$ 側 & 1.59 & \multirow{2}{*}{1.59} \\
\hline & 一 側 & 1.59 & \\
\hline
\end{tabular}

の部分を含まないので検出部全体の時定数ではないが， 測定電極を通過するスライバの速度が大きい場合には， 電極幅の影響はほとんど無視できるから，検出部の時定
数は Normal の場合でほぼ $0.2 \mathrm{sec}$, Inert の場合で 1.6 $\sec$ として扱って大差はない.

\section{4. む む}

以上が本研究に使用するスライバ太さ自動制御装置の 構成と検出部特性の概要であるが，検出部の静特性につ いては，さらに次報でくわしく報告する予定である。

\section{文献}

1) アメリカ特許 No. 305654

2 ）菟頭；本誌，11，10

3）井原, 高木, 佐藤; 本誌, 15,$10 ; 16,3$

4) 横河電機；EH-21 電気一油圧式パワーアク夕説 明書

5 ）ウスタイフブネステスタ説明書

\section{紡織会社と紡 織機メ一カ}

労働力不足に伴なってオートメの大流行. 繊維 業界も御多聞にもれず語尾に A S S のつく連続紡 糸機が数種類になった。業界でもようやく Break through 思想の興隆．従来の人真似では追いつかな くなってきた。しかしよい.Idea す結局実施しなけ れば物の役に立たない。ここで機械メ一カの重要性 が認識され出してきた。機械を製造することのいか にむつかしく，骨の折れる仕事かといらことがわか ってきた。「従来のよい機械ができたらただで持っ てこい，使って見て採算に合うと思えば買上げてや， る」式の陉託宣はもはや通用しなくなった。

紡織業者の位置も低下し，十大紡といえどもとこ らの中企業の利益に劣るほどのものも出てきた。低 姿勢にならざるを得ない.一方メ一カのあるものは その子会社は実はいまでは親会社的存在になったが, その利益は日本銀行につぐ第 2 位を獲得し，乙かも 充分のレザーブを取り, 前途洋々たるものが現われ
るに至った。

それほどでなくとも紡織会社でコントロールして いる以外の数製造会社は兼業の助け歹あって異常の 発展を遂げ，その多くは金払いの悪い内地繊維業者 を嫌って，政府の方針にしたがいじきに金になる輸 出に専念するようになった。なんのことはない内地 で試験ずみの新鋭機械を外国製品之対抗上低開発国 はすちろんかっての紡機の御師匠さんであったイギ リスにさえも輸出しよ5としている。しかしそれに しては万国博覧会への出品が他国に比してはなはだ 貧弱なのはどういらわけか。京た低開発国の金融事 情や先進国の関帨の障壁など苦しい時期を迎えねば なるまい.いずれにしても繊維業者と機械メ一カが 対等の位置になったということは今後の発展に大い に寄与することと思う. 参考のため下記アメリカに おける繊維機械製造の状況を金額で現わしたものを 摘記する。

(T.F.)

アメリカに和ける緎維機械製造の推移状况

\begin{tabular}{|c|c|c|c|c|c|c|}
\hline \multirow{2}{*}{ 年度 } & \multicolumn{2}{|c|}{$\begin{array}{c}\text { アメリカの綫維機械総生産高 } \\
\text { (輸出を含む) }\end{array}$} & \multicolumn{2}{|c|}{$\begin{array}{l}\text { 外国製酨維機械のアメリカ } \\
\text { への輸入高 }\end{array}$} & \multicolumn{2}{|c|}{ アメリカ製織維機器の輸出高 } \\
\hline & $\$$ & 円 & $\$$ & 円 & $\$$ & 円 \\
\hline 1950 & 456000000 & 1642 億 & 4200000 & 15億 4千 & 99600000 & 358 譩 \\
\hline $\begin{array}{c}1951 \\
\vdots \\
1962\end{array}$ & $\begin{array}{c}499000000 \\
\vdots \\
532427000\end{array}$ & $\begin{array}{c}1792 \text { 億 } \\
\vdots \\
1917 \text { 億 }\end{array}$ & $\begin{array}{c}6900000 \\
\vdots \\
39900000\end{array}$ & $\begin{array}{c}24 \text { 億 } 8 千 \\
\vdots \\
143 \text { 億 }\end{array}$ & $\begin{array}{c}107700000 \\
\vdots \\
132000000\end{array}$ & $\begin{array}{c}388 \text { 億 } \\
\vdots \\
475 \text { 億 }\end{array}$ \\
\hline 1963 & 550000000 & 1980 億 & 40000000 & 144 億 & 110000000 & 396 億 \\
\hline \multicolumn{7}{|c|}{$<$ 参 考 $>$} \\
\hline & \multicolumn{2}{|c|}{ 日本の縅維機械総生産高 } & \multicolumn{2}{|c|}{$\begin{array}{l}\text { 外国製繊維機械の日本への } \\
\text { 輸入高的 }\end{array}$} & \multicolumn{2}{|c|}{ 日本製繊維機械の輸出高 } \\
\hline 年 度 & \multicolumn{2}{|c|}{ 円 } & \multicolumn{2}{|c|}{ 円 } & \multicolumn{2}{|c|}{ 円 } \\
\hline 1962 & \multirow{2}{*}{\multicolumn{2}{|c|}{$\begin{array}{l}64.4 \text { 億 } 6 \text { 千 } 800 \text { 万 } . \\
666 \text { 億 } 8 \text { 千 } 600 \text { 万 }\end{array}$}} & \multirow{2}{*}{\multicolumn{2}{|c|}{$\begin{array}{l}255 \text { 億 } 9 \text { 千 } 100 \text { 万 } \\
193 \text { 億 } 8 \text { 千 } 100 \text { 万 }\end{array}$}} & \multirow{2}{*}{\multicolumn{2}{|c|}{$\begin{array}{l}95 \text { 億 } 1 \text { 千 } 500 \text { 万 } \\
180 \text { 億 } 4 \text { 千 } 700 \text { 万 }\end{array}$}} \\
\hline 1963 & & & & & & \\
\hline
\end{tabular}

